\title{
Effect of Nitrogen Fertilizers on Yield and Antioxidant Enzymes of Basil (Ocimum basilicum L.) under Water Stress Conditions
}

\author{
Amir Rahimi (Corresponding author's) \\ Urmia University, Faculty of Agriculture, Department of Agronomy, Urmia/Iran \\ E-mail: e.rahimi@urmia.ac.ir; emir10357@gmail.com \\ Fatemeh Ahmadi \\ Urmia University, Faculty of Agriculture, Department of Soil Science, Urmia/Iran \\ E-mail: fa.ahmadi@urmia.ac.ir \\ Gulen Ozyazici \\ Siirt University, Faculty of Agriculture, Department of Field Crops, Siirt/Turkey \\ E-mail:gulenozyazici@siirt.edu.tr
}

\begin{abstract}
Water scarcity in Iran has always been a limiting factor for crop and horticultural production. Under these conditions, the nutrient uptake and metabolism processes of plants are different and can reduce growth. To study water stress (at three levels) and six fertilizer regimes (Nitrogen fertilizer requirement by a combination of vermicompost and urea fertilizer) on the quantitative yield of experimental basil (Ocimum basilicum L.). Results showed that water deficit treatment reduced leaf chlorophyll content, leaf soluble proteins, shoot dry weight and essential oil yield. The highest concentration of total chlorophyll and leaf soluble protein was obtained in normal irrigation and fertilizer regime of 1 ton vermicompost. And water deficit stress reduced these two traits. The lowest activity of antioxidant enzymes was obtained under non-stress conditions. Increasing of water deficit stress increased the activity of these antioxidants among fertilizer treatments. The highest activity of this antioxidant was obtained in non-fertilizer treatment and by adding vermicompost fertilizer to fertilizer treatment of this antioxidant. Forks also declined. The shoot dry weight and essential oil yield decreased under water deficit stress. Increasing vermicompost share in fertilizer treatments led to increased yield. The percentage of essential oil increased with moderate irrigation and decreased again with severe irrigation. In general, the results showed that vermicompost had a positive effect on both vegetative and physiological traits of the plant.
\end{abstract}

Keywords: Catalase, Compost, Peroxidase, Secondary metabolites, Urea fertilizer

DOI: $10.7176 / J S T R / 5-11-12$

\section{Introduction}

Iran with an average rainfall of $250 \mathrm{~mm}$ per year is classified as arid and semi-arid regions of the world. Insufficient rainfall and uneven distribution during the growing season in areas such as Iran has caused the water requirement of crops and orchards to be insufficiently provided (Amiri et al., 2018). Therefore, exposure of plants to water deficit stress is inevitable, especially at some times of the year (Moghavi et al., 2019). The impact of water deficit stress on crops in Iran has been studied in detail, but unfortunately, less detailed and comprehensive research has been done on medicinal plants that may even have a positive effect on their medicinal properties (Pandey et al., 2005).

Drought stress occurs in plants when the amount of water received is less than the loss, which may be due to excessive water loss or reduced absorption or both (Zehtabe-Salmasi et al., 2008). Drought stress affects photosynthetic pigments in plants. Low concentrations of photosynthetic pigments can directly decrease photosynthesis ability and reduce the initial production of the product (Prasad et al., 2004; Zand et al., 2017). During drought stress, plants try to relieve stress by storing osmotic regulators such as amino acids, sugars, hormones and some minerals (Mohammadkhani et al., 2007). Moisture stresses are highly correlated with

$100 \mid \mathrm{P}$ a g e

www.iiste.org 
plant nutrition. One of the major negative effects of drought stress is the reduction of nutrient availability and uptake for plants. The effect of drought stress on essential oil of basil was found to be significantly increased under drought conditions (Nasiri et al., 2010). Nitrogen fertilizers increase the yield of basil (Ocimum basilicum L.) foliage (Masood et al., 2006). It was found that instead of continuous use of chemical fertilizers, optimum use of organic fertilizers for sustainable agriculture and reduction of pollution caused by the use of chemical fertilizers can be stepped in the production of medicinal plants (Venkateswaran et al., 2007).

Nitrogen is involved in the formation of many plant organic compounds and has positive effects on plant growth due to its positive effects on photosynthetic activity and metabolic processes of organic compounds in the plant and enhance vegetative growth (Singh et al., 2004). So, good nutrition of plants plays an important role in their resistance to various types of living and non-living stresses (Marrelli et al., 2018). A plant that is well-nourished and has sufficient nutrients will have better resistance to dehydration and will be affected by the quantity and quality of the product. On the other hand, increased plant growth through the application of nutrients under drought conditions can facilitate the extraction of water and nutrients from deeper layers of soil (Moreno et al., 2018). Basil (Ocimum basilicum L.) is an annual, or sometimes perennial, herb used for its leaves. Depending on the variety, plants can reach between $30 \mathrm{~cm}(0.98 \mathrm{ft})$ and $150 \mathrm{~cm}$ ( $4.9 \mathrm{ft})$ (Singh et al., 2004). Its leaves are richly green and ovate, but otherwise come in a wide variety of sizes and shapes depending on cultivar. Leaf sizes range from $3 \mathrm{~cm}$ (1.2 in) to $11 \mathrm{~cm}$ (4.3 in) long, and between $1 \mathrm{~cm}(0.39 \mathrm{in})$ and $6 \mathrm{~cm}$ (2.4 in) wide (Moreno et al., 2018). The plant grows a thick, central taproot. Its flowers are small and white, and grow from a central inflorescence that emerges from the central stem atop the plant Most of the damage in plants, which is caused by different stresses, is related to oxidative damage at different cellular levels (Raymond et al., 1993). Effect of water deficit stress on growth by reducing turgidity and cell growth, reducing light absorption and total photosynthetic capacity of plant, especially in shoots and leaves, decreases plant growth as well as delaying germination (Hosni et al., 2002; Bhardwaj and Dubey, 2019).

The earliest effects of water deficit stress can be related to the closure of the photosynthetic system, the breakdown of the electron transport chain and the production of free or reactive oxygen, $\mathrm{O}_{2}, \mathrm{H}_{2} \mathrm{O}_{2}$ and $\mathrm{OH}$ (Bonea and Urechean, 2018). Because of their high affinity for oxygen radicals, they degrade cell membranes, enzymes, nucleic acids and cellular proteins. Plants use chlorophyllase to counteract and damage free radicals to reduce the activity of chlorophyll and many antioxidants such as superoxide dismutase (SOD), catalase (CAT) and peroxidase (POX). The balance in the activity of these enzymes in the cell determines the amount of free radicals and hydrogen peroxide $\left(\mathrm{H}_{2} \mathrm{O}_{2}\right)$ (Masood et al., 2006).

Although there are a lot of studies on antioxidant enzymes activities in all over the world, there is little information on the enzymes activity under stress conditions. So, the aim of this study were investigate the effect of water stress conditions and various fertilizer loading on catalase and peroxidase antioxidant enzymes activity in root and shoot tissues.

\section{Material and Methods}

In this regard, to study water stress (at three levels) and six levels of fertilizer (providing nitrogen fertilizer required by a combination of vermicompost and urea fertilizer) on the qualitative and quantitative yield of peppermint medicinal plant in 1396. A split plot design was conducted in a randomized complete block design with three replications. Irrigation regimes including irrigation after $25 \%$ moisture content at root development depth (non-stress), irrigation after $40 \%$ moisture content at root development depth (medium stress) and irrigation after 55\% moisture content at depth. Root development (severe stress) and six fertilizer treatments including without fertilizer $\left(\mathrm{F}_{1}\right), 90 \mathrm{~kg}$ urea fertilizer $\left(\mathrm{F}_{2}\right), 70 \mathrm{~kg}$ urea +1 ton ha ${ }^{-1}$ vermicompost $\left(F_{3}\right), 60 \mathrm{~kg}$ urea +1 ton ha ${ }^{-1}$ vermicompost $\left(\mathrm{F}_{4}\right), 30 \mathrm{~kg}$ urea +1 ton ha ${ }^{-1}$ vermicompost $\left(\mathrm{F}_{5}\right)$ and 1 ton ha ${ }^{-1}$ vermicompost $\left(\mathrm{F}_{6}\right)$ were considered. The amount of nitrogen and vermicompost fertilizer consumed was calculated according to the amount of nitrogen available in the soil and the need for the plant to achieve optimum yield. In this way, the urea fertilizer was fully applied immediately after cultivation in a watersoluble manner (Figure 1).

101 | P a g e

www.iiste.org 

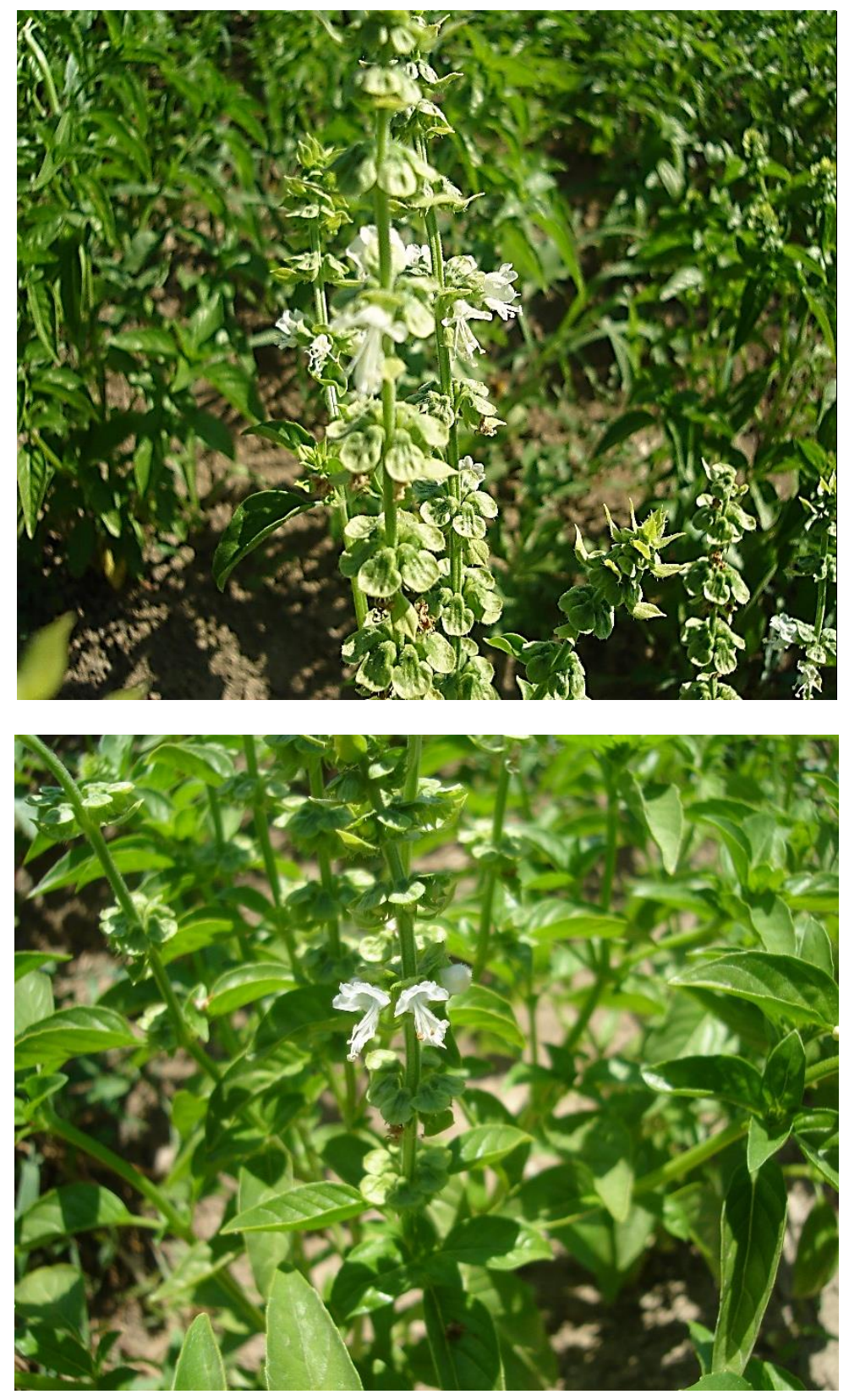

Figure 1. The Ocimum basilicum L. grown in open field condition

Vermicompost was also added to the soil before cultivation. Drip irrigation was done using irrigation tapes. Each experimental unit consisted of six rows of planting $35 \mathrm{~cm}(210 \mathrm{~cm}$ wide $)$ with a length of four meters and a distance of about $25 \mathrm{~cm}$ between plants. After 30 days of cultivation, irrigation treatments were applied. Before that, all plants were irrigated equally and when soil moisture was at $75 \%$ of field capacity. Soil water content was determined using TDR at the specified depth. Also, the pipes equipped with meters were used to determine and control the amount of irrigation water. Finally, for sampling (shoot and root) at $10 \%$ flowering, the plants were cut from a distance of $5 \mathrm{~cm}$ from the soil surface and the percentage of essential oil, dry matter yield and essential oil were measured. Pre-harvest levels of chlorophyll (Arnon, 1949; Bradford, 
1976), leaf soluble proteins (Bradford, 1976) and catalase antioxidants (Cakmak et al., 1991), peroxidase (Ghanati et al., 2002) and superoxide dismutase (Giannopolitis and Ries et al., 1977) were measured.

\section{Results and Discussion}

Results of analysis of variance indicated that all studied traits were affected by water deficit, fertilizer or their interactions. The highest concentration of total chlorophyll was obtained in normal irrigation and fertilizer regime of 1 ton vermicompost (Table 1). In this trait, dehydration stress decreased total chlorophyll concentration as well as severe dehydration and non-fertilizer treatment had the lowest total chlorophyll concentration. The highest concentrations of leaf soluble proteins were obtained under non-stress conditions. Protein content decreased with increasing water deficit stress. Increasing the amount of vermicompost fertilizer in the fertilizer treatment increased the concentration of leaf soluble proteins. The lowest activity of superoxide dismutase was obtained under non-stress conditions.

Table 1. Variance analysis and average values of studied properties under water stress condition and fertilizers

\begin{tabular}{ccccc}
\hline Treatments & chlorophyll & Soluble protein & Essential oil & Essential oil yield \\
\hline Water stress condition & $(\mathrm{mg} / \mathrm{g} \mathrm{FW})$ & $(\mathrm{mmol} / \mathrm{g} \mathrm{FW})$ & $(\%)$ & $(\mathrm{kg} / \mathrm{ha})$ \\
Without stress & $3.7^{\mathrm{a}}$ & $56.8^{\mathrm{c}}$ & $0.9^{\mathrm{a}}$ & $39.5^{\mathrm{a}}$ \\
Medium stress & $3.0^{\mathrm{b}}$ & $90.0^{\mathrm{a}}$ & $1.0^{\mathrm{a}}$ & $32.5^{\mathrm{b}}$ \\
High stress & $2.5^{\mathrm{c}}$ & $72.5^{\mathrm{b}}$ & $0.6^{\mathrm{b}}$ & $16.2^{\mathrm{c}}$ \\
Fertilizer treatments & & & & \\
$\mathrm{F}_{1}$ & $2.4^{\mathrm{c}}$ & $62.8^{\mathrm{c}}$ & $0.7^{\mathrm{c}}$ & $18.4^{\mathrm{d}}$ \\
$\mathrm{F}_{2}$ & $2.4^{\mathrm{b}}$ & $68.0^{\mathrm{bc}}$ & $0.8^{\mathrm{b}}$ & $26.5^{\mathrm{c}}$ \\
$\mathrm{F}_{3}$ & $3.1^{\mathrm{b}}$ & $69.9^{\mathrm{b}}$ & $0.8^{\mathrm{ab}}$ & $27.9^{\mathrm{c}}$ \\
$\mathrm{F}_{4}$ & $3.1^{\mathrm{b}}$ & $74.1^{\mathrm{b}}$ & $0.9^{\mathrm{a}}$ & $32.7^{\mathrm{b}}$ \\
$\mathrm{F}_{5}$ & $3.5^{\mathrm{b}}$ & $81.1^{\mathrm{a}}$ & $0.9^{\mathrm{a}}$ & $35.2^{\mathrm{ab}}$ \\
$\mathrm{F}_{6}$ & $3.6^{\mathrm{a}}$ & $82.6^{\mathrm{a}}$ & $0.9^{\mathrm{a}}$ & $37.6^{\mathrm{a}}$ \\
& & & $* *$ & $* *$ \\
Water stress & $* *$ & $* *$ & $* *$ & $* *$ \\
Fertilizer treatment & $* *$ & $\mathrm{~ns}$ & $*$ & $* *$ \\
Interactions & $\mathrm{ns}$ & 8.6 & 11.6 & 13.6 \\
CV $(\%)$ & 10.9 & & $* *$ & \\
\hline
\end{tabular}

$\mathrm{F}_{1}$ : without fertilizer, $\mathrm{F}_{2}: 90 \mathrm{~kg}$ Urea, $\mathrm{F}_{3}: 70 \mathrm{~kg}$ Urea+ vermicompost, $\mathrm{F}_{4}: 60 \mathrm{~kg}$ urea+ vermicompost, $\mathrm{F}_{5}: 30$ $\mathrm{kg}$ Urea+ vermicompost, $\mathrm{F}_{6}$ : vermicompost

*: Significance at 5\% level; **: Significance at $1 \%$ level; ns: No Significance 
With increasing water stress intensity, antioxidant activity was increased so that the highest activity was observed under severe stress conditions. The highest antioxidant activity was observed among the nonfertilizer treatments. Catalase antioxidant activity was also affected by fertilizer treatment and irrigation regimes, which increased with increasing water deficit stress. Also, non-fertilizer treatment had the highest amount of catalase antioxidant activity in the plant. The antioxidant peroxidase was also affected by the two treatments as the previous two antioxidants. The antioxidant activity increased with increasing water deficit stress. Antioxidant activity was also decreased by adding vermicompost fertilizer to fertilizer treatment. The shoot dry weight and essential oil yield were both decreased under water deficit stress. Also, increasing the vermicompost share in fertilizer treatments led to an increase in yield, so that 1 ton vermicompost treatment showed the highest yield compared to pure urea fertilizer treatment. Essential oil percentage was also affected by significant gradient water deficit treatment and increasing the water deficit intensity decreased the essential oil percentage. Increased level of vermicompost in fertilizer treatments reduced the severity of stress damage (Chen et al., 2008; Amini et al., 2018). Vermicompost appears to have a positive effect on antioxidant activity and peppermint biomass production through its high water uptake and nutrient intake. Organic fertilizer also increased the microbial population by improving physical conditions and soil vital processes, stability and buffering in the medium. Increasing enzymatic activity and the presence of beneficial microorganisms and hormones while creating a suitable environment for root growth, increase shoot growth and produce more dry matter (Ram et al., 2006; Jun et al., 2009).

Figures 2 and 3 show the effect of various drought and fertilizer levels on antioxidant enzyme (catalase and peroxidase) activity in root and shoot parts of basil (Ocimum basilicum L.) respectively. As shown in Figure 2 , the antioxidant activity of catalase and peroxidase enzymes were decrease by increasing of water stress level. The highest antioxidant activity of catalase and peroxidase enzymes were observed in without water stress conditions (3.5 and $2.9 \mu \mathrm{mol} / \mathrm{min} / \mathrm{g}$ FW respectively). Similar results were found by Yardanova et al (2004). Two times increase in antioxidant activity of catalase and peroxidase enzymes in without water stress conditions were reported by Foyer and Nocter (2003). The antioxidant activity of catalase enzyme was higher in root tissue than shoot. Same results were obtained for peroxidase enzyme. Same results were found by Venkateswaran et al (2007). According to Figure3, the antioxidant activity of catalase enzyme was higher in $F_{1}, F_{2}$, and $F_{4}$ treatments in different fertilizer levels and root tissues. The fluctuated trend was obtained for the antioxidant activity of peroxidase enzyme with different fertilizer levels in shoot tissue. In order to counteract the oxidative stress created in plants, the high performance antioxidant defense system in plants can neutralize free radicals in plants (Nautiyal et al., 2002). It contains antioxidant enzymes such as catalase, superoxide dismutase, ascorbate peroxidase, phenol peroxidase, and a non-enzymatic antioxidant system including ascorbate, carotenoids, phenolic compounds and proline (Dat et al., 2000). Plants with higher carotenoid content are more successful in protecting against reactive oxygen species and are better tolerated under water scarcity (Baysal and Tipırdamaz, 2010).

104 | P a g e

www.iiste.org 
International Journal of Scientific and Technological Research

ISSN 2422-8702 (Online), DOI: 10.7176/JSTR/5-11-12

Vol.5, No.11, 2019
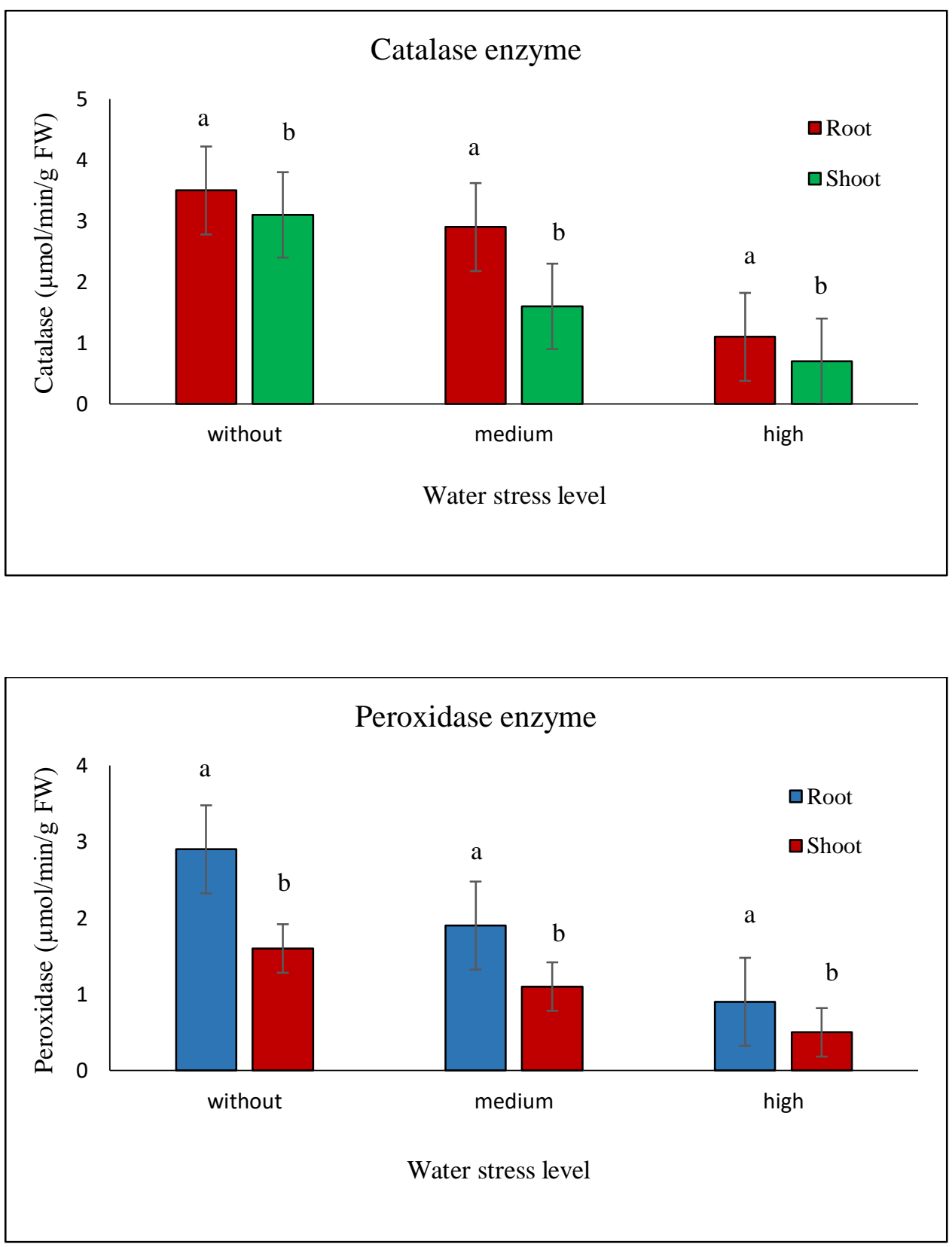

Figure 2. The effect of different drought levels on antioxidant enzymes activity in basil (Ocimum basilicum L.) 
International Journal of Scientific and Technological Research

ISSN 2422-8702 (Online), DOI: 10.7176/JSTR/5-11-12

Vol.5, No.11, 2019
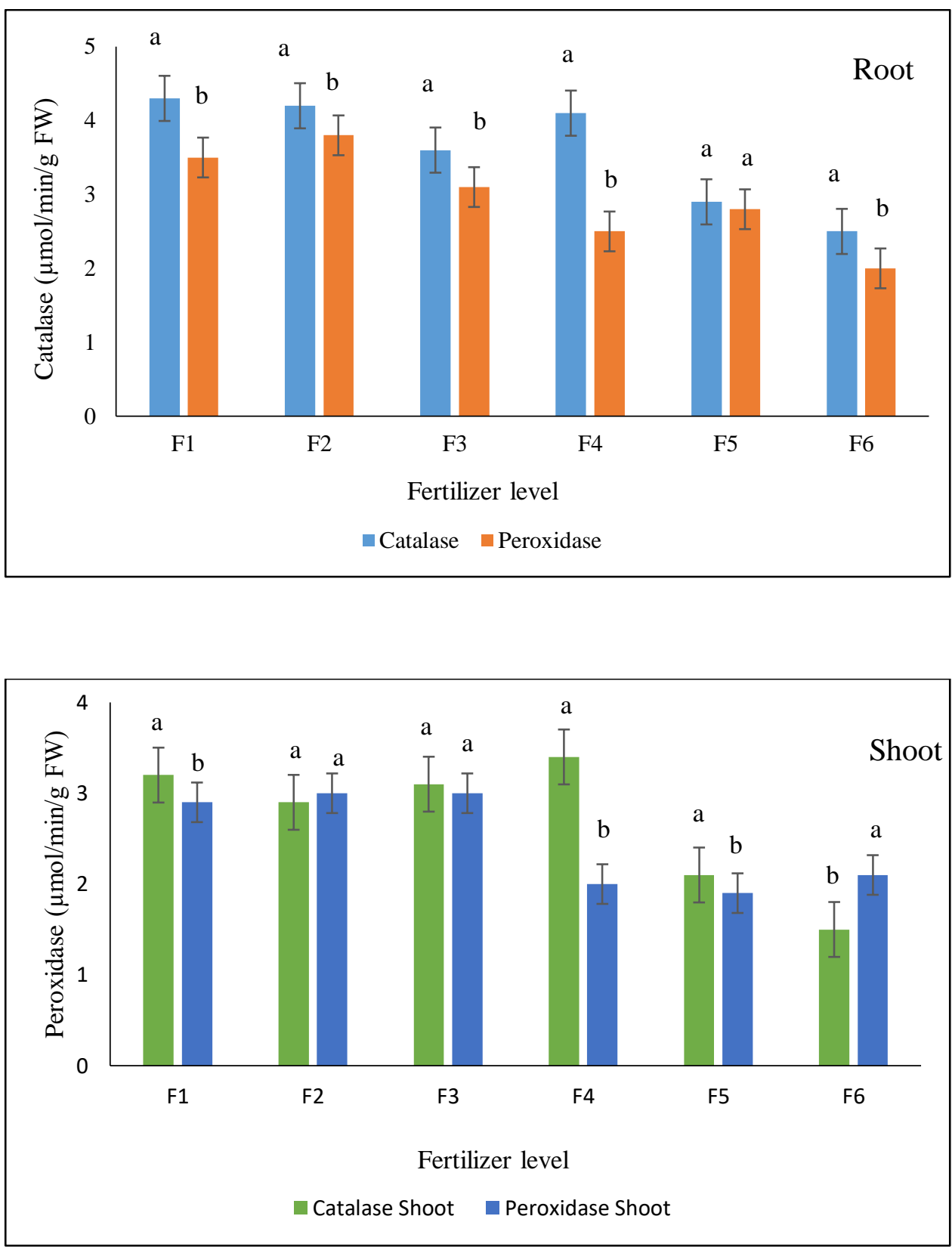

Figure 3. The effect of different fertilizer levels on antioxidant enzymes activity in basil (Ocimum basilicum L.) 


\section{Conclusion}

To study water stress (at three levels) and six fertilizer regimes (Nitrogen fertilizer requirement by a combination of vermicompost and urea fertilizer) on the quantitative yield of experimental basil (Ocimum basilicum L.). Results showed that water deficit treatment reduced leaf chlorophyll content, leaf soluble proteins, shoot dry weight and essential oil yield. The highest concentration of total chlorophyll and leaf soluble protein was obtained in normal irrigation and fertilizer regime of 1 ton vermicompost. And water deficit stress reduced these two traits. The lowest activity of antioxidant enzymes was obtained under nonstress conditions. Increasing of water deficit stress increased the activity of these antioxidants among fertilizer treatments. The highest activity of this antioxidant was obtained in non-fertilizer treatment and by adding vermicompost fertilizer to fertilizer treatment of this antioxidant. Forks also declined. The shoot dry weight and essential oil yield decreased under water deficit stress. Increasing vermicompost share in fertilizer treatments led to increased yield. The percentage of essential oil increased with moderate irrigation and decreased again with severe irrigation. In general, the results showed that vermicompost had a positive effect on both vegetative and physiological traits of the plant.

Declarations of interest: The authors declare that they have no conflict of interest.

\section{References}

Arnon, D.I. (1949). Copper enzymes in isolated chloroplasts. Polyphennoloxidase in Beta vulgaris. Plant Physiol, 24(1): 1-15.

Amiri, N., Yadegari, M., Hamedi, B. (2018). Essential oil composition of Cirsium arvense L. produced in different climate and soil properties. Records of Natural Products, 12(3): 251-262.

Bonea, D., Urechean, V. (2018). Effect of sweet marjoram (Origanum majorana L.) cogermination and aqueous extracts on maize (Zea mays L.). In "Agriculture for Life, Life for Agriculture" Conference Proceedings, 1(1):11-16.

Bhardwaj, K., Dubey, W. (2019). Quantitative analysis of primary and secondary metabolites of ethanol seed extract of Origanum majorana (marjoram). Journal of Pharmacognosy and Phytochemistry, 8(1): 1251-1255.

Bradford, M. (1976). A rapid and sensitive method for the quantitation of protein utilizing the principle of protein-dye binding. Annual Review Biochemistry, 72:248-254.

Baysal Furtana, G. Tipırdamaz, R. (2010). Physiological and antioxidant response of three cultivars of cucumber (Cucumis sativus L.) to salinity. Turkish Journal of Biology, 34: 287-296.

Borsanio O., Valpuesta V., Botella M.A. (2001). Evidence for a role of salicylic acid in the oxidative damage generated by $\mathrm{NaCl}$ and osmotic stress in Arabidopsis seedlings. Plant Physiol., 26: 10241030.

Cakmak, I. and Horst, W. (1991). Effect of aluminium on lipid peroxidation, superoxide dismutase, catalase and peroxidase activities in root tip of soybean (Glysin max). Plant Phisiology.83: 463-468.

Chen L.Q., Guo Y.F., Yang L.M., Wang Q.Q. (2008). Synergistic defensive mechanism of phytochelatin and antioxidative enzymes in Brassica chinensis L. against Cd stress. Chinese Science Bulletin, 53:1503-1511.

107 | P a g e

www.iiste.org 
Dat, J., Vandenabeele, S., Vranova, E., Van Montagu, M., Inze, D. Van Breusegem, F. (2000). Dual action of active oxygen species during plant stress responses. Cellular Molecular of Life Science, 57: 779795.

Foyer C.H., Nocter G. (2003). Redox sensing and signaling associated with reactive oxygen in chloroplasts, peroxisomes and mitochondria. Physiologia Plantarum, 119(3): 355-364.

Ghanati, F., Morita, A., Yokota, H. (2002). Induction of suberin and increase of lignin content by excess boron in Tabacco cell. Soil Science, Plant Nutrition, 48(3): 357-364.

Giannopolitis, C., Ries, S. (1977). Superoxid dismutase: I. Occurence in higher plants. Plant Physiology, 59(2): 309-314.

Han F.X., Maruthi Sridhar B.B., Monts D.L., Su Y. (2004). Phytoavailability and toxicity of trivalent and hexavalent chromium to Brassica juncea. New Phytologist, 162(2): 489-499.

Jun R., Ling T., Guanghuz Z. (2009). Effects of chromium on seed germination, root elongation and coleoptiles growth in six pulses. International Journal of Environmental Science \& Technology, 6(4): 571-578.

Moreno, Y., Arteaga-Miñano, H. (2018). Natural conservation of guinea pig (Cavia porcellus) meat vacuum packed: Oregano essential oil effect on the physicochemical, microbiological and sensory characteristics. Scientia Agropecuaria, 9(4): 467-476

Marrelli, M., Statti, G. A., Conforti, F. (2018). Origanum spp.: an update of their chemical and biological profiles. Phytochemistry Reviews, 17(4): 873-888.

Moghavi, A., Sahakyan, N., Babayan, A., Chichoyan, N., Petrosyan, M., Trchounian, A. (2019). Essential oil and ethanol extract of oregano (Origanum vulgare L.) from Armenian flora as a natural source of terpenes, flavonoids and other phytochemicals with antiradical, antioxidant, metal chelating, tyrosinase inhibitory and antibacterial activity. Current Pharmaceutical Design, 25(16): 1809-1816.

Masood A., Shab N.A., Zeeshan M., Abraham G. (2006). Differential response of antioxidant enzeme to salinity stress in two varieties of Azolla (Azolla pinnata and Azolla filiculcides). Environmental and Experimental Botany, 58(1-3): 216-222.

Mohammadkhani, N. and Heidari, R. (2007). Effects of water stress on respiration, photosynthetic pigments and water content in tow maize cultivar. Pakistan Journal of Biological Science, 10(22): 4022-4028.

Nautiyal, P. C., Rachaputi, N. R. Joshi, Y. C. (2002). Moisture-deficit-induced changes in leaf-water content, leaf carbon exchange rate and biomass production in groundnut cultivars differing in specific leaf area. Field Crops Research, 74(1): 67-79.

Nasiri. Y., Zehtabe-Salmasi, S., Nasrollahzade, S., Najafi, N. Ghassemi-Golezani, K. (2010). Effect of foliar application of micronutrient ( $\mathrm{Fe}$ and $\mathrm{Zn}$ ) on flower yield and essential oil of chamomile (Matricaria chamomila L.). Journal of Medicinal Plants Research, 4(17): 1733-1737.

Pandey V., Dixit V., Shyam R. (2005). Antioxidative responses in relation to growth of mustard (Brassica juncea cv. Pusa Jaikisan) plants exposed to hexavalent chromium. Chemosphere, 61(1): 40-47.

108 | P a g e

www.iiste.org 
Prasad, S.P., Ram, C. Uma, S. (2004). Effect of water logging duration on chlorophyll content, nitrate reeducates activity, soluble sugars and grain yield of maize. Annals of Plant Physiology, 18(1): 1-5.

Ram, D., Ram, M., Singh, R. (2006). Optimization of water and nitrogen application to menthol mint (Mentha arvensis L.) through sugarcane trash mulch in a sandy loam soil of semi-arid subtropical climate. Bioresource Technology, 97(7): 886-893.

Raymond M., Poulin E., Boirox V., Dupont E., Pasteur N. (1993). Stability of insecticide resistance due to amplification of esterase genes in Cluex pipiens. Heredity, 70: 301-307.

Singh S., Saxena R., Pandey K., Bhatt K., Sinha S. (2004). Response of antioxidants in Helianthus annuus L. grown different amendments of tannery sludge: Its metal accumulation potential. Chemosphere, 57(11): 1663-1673.

Terzi R., Sağlam A., Kutlu N., Nar H., Kadioglu A. (2010). Impact of soil drought stress on photochemical efficiency of photosystem and antioxidant enzyme activities of Phaseolus vulgaris cultivars. Turkish Journal of Botany, 34:1-10.

Venkateswaran P., Vellaichamy S., Palanivelu, K. (2007). Speciation of heavy metals in electroplating industry sludge and wastewater residue using inductively coupled plasma. International Journal of Environmental Science \& Technology, 4(4): 497-504.

Yardanova R.Y., Christov K.N., Popova L.P. (2004). Antioxidative enzyme in barley plants subjected to soil flooding. Environmental and Experimental Botany, 51(2): 93-101.

Zand, A., Aroiee, H., Chaichi, M.R. Nemati, S.H. (2017). Effects of bio-fertilizers on some physiological characteristics, essential oil percentage and yield of spearmint (Mentha spicata L.) under deficit irrigation. Iranian Journal of Medicinal and Aromatic Plants, 33(1): 112-125.

Zehtabe-Salmasi, S., Heidari, F. Alyari, H. (2008). Effect of microelements and plant density on biomass and essential oil production of peppermint (Mentha piperita L.). Plant Science Research, 1(1): 24-28. 